\title{
Male and Female Finds and Symbols in Germanic Iron Age Graves
}

\author{
Bo Petré
}

\begin{abstract}
Finds and symbols specific for male respectively female graves from the Germanic Iron Age have been studied for the Mälar area. A preliminary list with weapons, tools and jewellery is presented.
\end{abstract}

Bo Petré. Department of Archaeology, Stockholm University. S-106 91 Stockholm. Sweden.

\section{INTRODUCTION}

Male and female finds and symbols in graves have not been given especially great attention in archaeological research. In this paper several suggestions concerning the sex determination of certain grave finds in cremation graves from the Late Iron Age, specifically the Germanic Iron Age, will be presented. The material is taken primarily from the Mälar area where a large number of cremation graves have been investigated in connection with general exploitation and the expansion of modern-day society during the past 30 years. This presentation is in no way complete, general or final, but should be seen as a preliminary report of a part of research in progress.

In order to determine the sex of a grave material, it is necessary that the material has grave goods which are possible to analyse methodically (for exemple, through analysis of find combinations) and also that there are independent variables which can be tested against the archaeological finds (for example, burned bones which can be analysed osteologically). Larger osteological analyses of prehistoric grave material are still a rarity.

During recent years, only a few sex determination analyses have been carried out on the relatively rich grave material from the Late Iron Age. From the Mälar area, sex analyses have been made on certain finds from grave material from the Migration Period (Bennett 1987) and the Late Iron Age (Petré 1984; 1992). In Denmark, among other things analyses have been done on Bronze Age material (Gibbs 1987) and on material from the Early and Late Iron Age (Sellevold et. al. 1984; Ringtved 1986; Jörgensen 1990:28). In Norway analyses have been made on grave material from the Early Iron Age (Hjörungdal 1991) and the Late Iron Age (Dommasnes 1979). All of these analyses share the common principal that weapons can be related to male graves and jewellery to female graves.

\section{SOME METHODOLOGICAL PROBLEMS}

The sex determination of an interred individual is not easily done. The point of departure is the bone material (the cremation tradition is the most common burial practice during the Iron Age), finds and implications of symbols (for example, grave construction). Three principle methods can be tested:

Osteological determination

Find association

Symbolic/religious/social meaning

It can be said that there are two independant methods and main principles for sex determination; osteological determination and archaeological determination.

The cremation grave tradition is, on the whole, the most common burial practice from the middle of the Bronze Age and continues on to the influence of Christianity in the $\mathrm{Vi}$ king Age. The remains of the burned bone 
material are always crushed, usually in centimeter-large flakes, thus making it more difficult to determine sex. Osteological sex determinations must be based on general characteristically male or female traits which perhaps not always are present in each interred individual ("there can even have been graceful men and robust women"). Such characteristically sex-related bones may perhaps not always have been left in a grave; the volume of the bone material itself in a grave is nearly always smaller than the original volume which is really representative of an individual, that is $2.5-3.5$ liters burned bones. The average volume of burned bones in graves from the Late Iron Age should lie around 1 liter, and even then animal bones are also included, where dog, sheep/goat, fowl and swine are the most common (compare Petré 1984:1 10; Bennett 1987:111). Consequently, the bone material is not complete in the cremation graves, which further complicates the osteological analyses. How the c. two-thirds of the bone material disappeared is unclear, but it is probable that a reduction took place in connection with different rituals following the funeral pyre and crushing of the bones. Sex determinations are easier to do on unburned skeletons, but the inhumation graves are unusual (except during certain periods). In the inhumation graves from the Mälar area, the bone material has often disintegrated because of the soils' poor quality of preservation.

There are often several types of female as well as male finds in a grave. These may be a question of double graves. Here, an osteological analysis is important as a compliment to the so-called MIND-calculation. However, it is not always possible to osteologically identify several individuals in a grave material because of the above comments.

In relation to grave finds, there may be a problem of interpretation as to just what the deposited finds really represent; the personal goods and everyday dress of the deceased?, the deceased's family's choice of objects? clan or family-related indications of status?, or special equipment for the deceased's final journey?, etc. A currently common interpretation is that the grave finds primarily represent everyday traditions in dress (Gebühr 1976:176; Bennett 1987:1 10; Jörgensen 1990:29, cf p.30).

Different grave constructions and details of constructions can have had a symbolic meaning in certain cases possibly tied to the different sexes. This seems to be true in the case of triangular stone settings with concave sides and four-sided stone settings and, in general, to graves with varied form which are more often related to male graves (Bennett 1987:147).

\section{MALE GRAVES}

\section{Weapon Graves}

Weapons are sometimes found in the grave material from the Late Iron Age, unfortunately in the form of fragments; a guard, for example. Completesword blades, sword points or lance points are rare and it is probable that those objects that were included in the grave ritual were "destroyed" in some form of liberation process of the same kind as for the body and soul; to get to "the other side", to be transformed through fire (and crushing); a kind of "disintegration" prior to rebirth reincarnation. Sword blades are, as a rule, not found in the cremation layer but guard details, for example, bear witness to the fact that weapons were originally present in the funeral pyre. The same situation may be applicable for lance points and spear points where, for example, rivet plates for lances or spears can be evidenced but not the blade itself (Petré 1984:204).

\section{Tools and Different Attachments}

Other objects which may also be included in male graves are flints for fire-making, strap buckles, strap runners, gaming pieces, dice, so-called double mounts, strap end mounts (strap tongues), strap mounts and belt mount rings with peripheral groove, awls and glass vessels(?). Bennett (1987:110) sees a connection between men and combs with handles and 
comb cases. One single red glass bead often appears in male graves. The find combination of one red glass bead and a flint for firemaking in many male graves is common.

\section{Grave Constructions / Constructional Details}

Certain grave constructions seem to be associated with males. There seems to be a connection between rectangular stone settings and male graves. There may even be sex associations for certain kinds of other socalled "varied grave forms" which are remnants from the Roman Iron Age. Three-sided stone settings with concave sides begin to appear during the Migration Period and seem (with some osteological exceptions) to be male graves (Carlsson 1990).

One certain male constructional detail in the grave material is a centrally placed raised stone. The symbol always indicates a male grave. What this implies symbolically is, however, not completely clear (compare Petré 1984:196). Raised stones occur in graves of males from all different age groups, for young boys as well as for middle-aged men and older men. Naturally formed stones have often been used during the Migration Period while worked stones are usual during the Late Iron Age (Petré 1984:37). A few examples of double graves with both a male and a female have raised stones. Sizeable stone fillings/stone settings related to their surrounding graves in a cemetery are very often male graves. This applies even for relatively large cremation layers and quantities of bone. These facts can, however, be difficult to measure.

It is interesting to note that calculations of average stone size in graves show greater values for male graves than for female graves (Petré 1984:199; Bennett 1987:160).

\section{FEMALE GRAVES}

\section{Jewellery and Dress Attachments}

Female graves have no weapon combinations. Here there is jewellery instead, certain tools or dress attachments, for example fibulas (many different types during the Migration Period and the Vendel Period), beads ( $>3$ beads), dress pins, pendants, ringed tool brooches with toiletry sets (tweezers, ear spoons, tongue scrapers, keys, etc.), small knives with angled backs and bone scrapers for skins.

\section{Grave Constructions / Constructional Details}

One certain constructional detail associated with female graves is the grave ball of stone (Petré 1981:14; 1984:39). The largest stone ball in a grave which has been excavated is the so-called Wälter's stone from Öland. The ball, which weighed 9 tons, was situated in the center of a female grave from the Late Roman Iron Age. There were also many infant skeletons in the grave (Lundh \& Rasch 1991). Neither is the symbolism for the grave ball known, except that it is related to female graves. Grave balls occur in different age groups, even in children's graves (girls) age $0-7$ years.

\section{Finds with Uncertain Sex Determination}

Finds which can be both male and female but in uneven frequency, at times appearing as only locally sex-related, are whetstones (more often in male graves), finger rings (more often in male graves during the Migration Period?), comb cases (more often in male graves), strap end mounts/strap tongues (more often in male graves).

\section{Changes and Local/Regional Variations}

As in the end of the $400 \mathrm{~s}$, great changes in the society also take place at the end of the $700 \mathrm{~s}$. Even the find context of graves changes. A new dress style is introduced for women (cf. Jörgensen 1990:94-95) and changes in the grave ritual can be evidenced in the cremation graves (Petré 1992).

Not least during the Viking Age are there regional as well as local differences concerning the relationship between types of finds 
and sex, but the main principles remain with weapons in male graves and jewellery in female graves. (Examples of regional differences are the animal-headed and the box-shaped brooches which appear exclusively in Gotland). Even the chronological aspects are important (compare, for example, the small equal-armed brooches during the 500 s which, in Finland, continue on into the Viking Age).

\section{SUMMARY}

It may be said that, in principle, weapons and weapon details and certain tools (strap mounts, buckles, flint for fire-making) belong specifically to male graves while jewellery (fibulas/ brooches, pendants, beads ( $>3$ ), arm and neck rings) and certain toiletries belong specifically to female graves.

Many types are common for both sexes. It should be emphasized that local as well as regional and chronological differences appear which means that general conclusions may not be drawn. Each region or site must be analysed in itself and receive its own evalua- tion in future research. Many times certain wear damages can be seen on, for example, jewellery and knives which can witness daily use. The interpretation of grave finds is that they very likely may be seen as representing the contemporary tradition in dress including accessories, tools and perhaps weapons which, in turn, in different combinations, can be related to the individuals' social position in the society.

In the tables below an attempt has been made towards a chronological presentation of specifically male respectively female-related grave finds for the Mälar area. The material is mainly taken from Petré 1984 and 1992, Bennett 1987, Ferenius 1971 and Modin 1973 but is even taken from several seminar papers in archaeology under my supervision. There is some doubt about certain finds which are indicated by "?" in the tables. The Birka material is, with its uniqueness, not taken into consideration in this preliminary presentation even if the majority of finds there seem to be congruent with the ideas presented here (cf. Gräslund 1980).

\begin{tabular}{|c|c|c|c|}
\hline Male Graves & $\begin{array}{l}\text { Migration } \\
\text { Period }\end{array}$ & $\begin{array}{l}\text { Vendel } \\
\text { Period }\end{array}$ & $\begin{array}{l}\text { Viking } \\
\text { Age }\end{array}$ \\
\hline $\begin{array}{l}\text { Weapons and weapon details } \\
\text { (swords, scramasax, lance, spears, } \\
\text { arrow points, shields) }\end{array}$ & $\mathrm{x}$ & $x$ & $x$ \\
\hline Strap buckle (Sw: sköldtornssölja) & $\mathrm{x}$ & $x$ & \\
\hline Buckle & $\mathrm{x}$ & $x$ & \\
\hline Strap end mount & $\mathrm{x}$ & $x ?$ & \\
\hline Double mount & $x$ & $(\mathrm{x})$ & \\
\hline Comb with handle & $\mathrm{x}$ & & \\
\hline$A w l$ & $\mathrm{x}$ & $\mathrm{x}$ & $?$ \\
\hline Flint for fire-making & $x$ & $\mathrm{x}$ & $x$ \\
\hline Strike-a-light & & & $x ?$ \\
\hline Gaming piece & $\mathrm{x}$ & $x$ & $\mathrm{x}$ \\
\hline Dice & $\mathrm{x}$ & $x$ & $\mathrm{x}$ \\
\hline Glass vessels & $x$ & $?$ & $?$ \\
\hline Penannular brooch & & & $\mathrm{x}$ \\
\hline Ringed pin & & & $\mathrm{x}$ \\
\hline Bow brooch & & & $\mathrm{x}$ \\
\hline I bead & $\mathrm{x}$ & $\mathrm{x}$ & $(\mathrm{x})$ \\
\hline Raised stone & $\mathrm{x}$ & $\mathrm{x}$ & $x$ \\
\hline Rectangular stone setting & $x$ & $\mathrm{x}$ & $?$ \\
\hline $\begin{array}{l}\text { Triangular stone setting } \\
\text { with concave sides }\end{array}$ & $x$ & $\mathrm{x}$ & $\mathrm{x}$ \\
\hline
\end{tabular}

The finds which with greatest certainty belong to male graves are weapons, flint for fire-making and raised stone. 
Male and Female Finds and Symbols 153

\begin{tabular}{|c|c|c|c|}
\hline Female Graves & $\begin{array}{l}\text { Migration } \\
\text { Period }\end{array}$ & $\begin{array}{l}\text { Vendel } \\
\text { Period }\end{array}$ & $\begin{array}{l}\text { Viking } \\
\text { Age }\end{array}$ \\
\hline Arm rings & & $x$ & $x$ \\
\hline Neck rings & $x$ & $x$ & $\mathrm{x}$ \\
\hline Temple rings & & & $x$ \\
\hline Brooches. fibulas & $x$ & $x$ & $\mathrm{x}$ \\
\hline Cross-shaped fibula & $x$ & & \\
\hline Square-headed brooch & $x$ & & \\
\hline Fibula of Husby typc & $x$ & & \\
\hline Beaked brooch & & $x$ & $(x)$ \\
\hline Crawfish brooch & $x$ & $(x)$ & \\
\hline Button-on-bow brooch & $\mathrm{x}$ & $x$ & $\mathrm{x}$ \\
\hline Equal-armed brooch (small) & $x$ & $(x)$ & \\
\hline Snake-shaped brooch & $x$ & $\mathrm{x}$ & \\
\hline Bird-shaped brooch & $x$ & $x$ & \\
\hline Quartrefoil brooch & & $x$ & \\
\hline Circular brooch (conical) & & $\mathrm{x}$ & \\
\hline S-shaped brooch & & $x$ & \\
\hline Oval brooch & & $x$ & \\
\hline Tortoise brooch & & & $x$ \\
\hline Equal-armed brooch (large) & & & $x$ \\
\hline Trefoil brooch & & & $\mathrm{x}$ \\
\hline Bronze chain & & $x$ & $\mathrm{x}$ \\
\hline Ringed tool brooch & $x$ & $x$ & $\mathrm{x}$ \\
\hline Skin scrapers & $x$ & & \\
\hline Dress pin & $x$ & $x$ & \\
\hline Beads $(>3)$ & $x$ & $x$ & $\mathrm{x}$ \\
\hline Bead string spacers & & $x$ & $\mathrm{x}$ \\
\hline $\begin{array}{l}\text { Coin (with edge hole/ suspension } \\
\text { eyelet) }\end{array}$ & & & $x$ \\
\hline $\begin{array}{l}\text { Toiletry set (for ex. ear spoon. } \\
\text { tweezers, longue scraper) }\end{array}$ & $x$ & $\mathrm{x}$ & $x$ \\
\hline $\begin{array}{l}\text { Key (can be included in } \\
\text { the above) }\end{array}$ & $x$ & $x$ & $x$ \\
\hline Grave ball (stone ball) & $x$ & $x$ & $x$ \\
\hline
\end{tabular}

The finds which with greatest certainty belong to female graves are libulas, beads (> 3) and grave balls. (An occasional male grave including brooches appears, compare Pelré 1984; Bennett 1987 ).

Translated by Phyllis Anderson. 


\section{REFERENCES}

Carlsson, M. 1990. En studie av undersökta treuddar $i$ Mälardalen och Östergötland. Seminar paper. Department of Archaeology. Stockholm university.

Bennett. A. 1987. Graven. Religiös och social symbol. Theses and papers in North-European Archaeology 18. Stockholm.

Dommasnes, L.H. 1979. Et gravmateriale fra yngre jernalder brukt til å belyse kvinners stilling. Viking 42. Oslo.

Ferenius, J. 1971. Värby och Värberg. En studie $i$ jänålderns bebyggelschistoria. Acta Universitatis Stockholmiensis. Suludes in North-European Archaeology, Series B. 1. Stockholm.

Hjörungdal, T. 1991. Det skjulte kjönn. Parriarkal tradisjon og feministisk visjon i arkeologien belyst med fokus pà en jernalderskontekst. Acta Archaeologica Lundensia. Series in $8^{\circ}$. Nr 19. Lund.

Gcbühr, M. 1976. Der Trachtschmuck der alleren römischen Kaiserzeit im Gebiet zwischen unterer Elbe und Oder und anf den westlichen dänischen Inseln. Götlinger Schriften zur vor- und frühgeschichte. Band 18 . Neumünster.

Gibbs, L. 1987. Identifying Gender Representation in the Archaeological Record: A Contexulual Study. The Archaeology of Conlextual Meanings. Ed. Hodder, I. Cambridge.
Gräslund, A.-S. 1980. Birka IV. The Burial Customs. A study of the graves on Björkö. KVHAA. Stockholm.

Jörgensen. L. 1990. Baekkegård and Glasergård. Two Cemeteries from the Late Iron Age on Bornholm. Arkaeologiske studier. Volume VIII. Köpenhamn. Lundh. K. \& Rasch, M. 1991. Ölands järnåldersgravfält. Volym ll. SHM/RÄ̈. Stockholm.

Modin, M. 1973. Tre järnåldersgardari Täby. Stockholm. Petré, B. 1981. Relationen mellan grav, gård och omland - exponering och kommunikation som funktion $i$ förhistoriska gravar med exempel från Lovö. Bebuggelsehistorisk tidskrift. $\mathrm{N}, 2$.

- 1984. Arkeologiska undersökningar på Lovö. Del 4. Bebyggelicarkeologisk analys. Acta Universitatis Stockholmiensis. Studies in North-European Archacology. 10. Stockholm.

- 1992. Gravälten Raä 13 och 16, Söderby, Lovö. Tvåfamiljegravfält frän yngre järnälder. Stockholm Archaeological Report. Field Studies. (in print).

Ringtved, J. 1986. Jyske gravfund fra yngre romertid. KUML 1986. Århus.

Sellevold. B.J., Lund Hansen, U. \& Balslev Jörgensen, J. 1984. Iron Age Man in Demmark. Prehistoric Man in Demmark vol III. Nordiske Forntidsminder ser.B bd 8 . Copenhagen. 